\title{
Roseicyclus mahoneyensis gen. nov., sp. nov., an aerobic phototrophic bacterium isolated from a meromictic lake
}

\author{
Christopher Rathgeber, ${ }^{1}$ Natalia Yurkova, ${ }^{1}$ Erko Stackebrandt, ${ }^{2}$ \\ Peter Schumann, ${ }^{2}$ J. Thomas Beatty ${ }^{3}$ and Vladimir Yurkov ${ }^{1}$ \\ ${ }^{1}$ The University of Manitoba, Department of Microbiology, 422 Buller Building, Winnipeg, MB, \\ Canada R3T 2N2 \\ ${ }^{2} \mathrm{DSMZ}$ - Deutsche Sammlung von Mikroorganismen und Zellkulturen GmbH, \\ Mascheroder Weg 1b, D-38124, Braunschweig, Germany \\ ${ }^{3}$ The University of British Columbia, Department of Microbiology and Immunology, \\ 300-6174 University Boulevard, Vancouver, BC, Canada V6T 1 Z3
}

Eight strains of Gram-negative bacteria able to form ring-like cells were isolated from Mahoney Lake, a meromictic lake in south-central British Columbia, Canada. All strains were pink-purple and contained bacteriochlorophyll a incorporated into the light-harvesting 1 and 2 and reaction-centre pigment-protein complexes. Growth did not occur anaerobically under illuminated conditions; these strains were obligately aerobic, prompting their designation as members of the aerobic phototrophic bacteria. Physiological characterization revealed that these isolates share a similar tolerance to high levels of salinity and $\mathrm{pH}$, as would be expected of bacteria from a highly saline lake; however, the strains exhibited marked differences in their ability to utilize organic substrates for aerobic heterotrophic growth. 16S rRNA sequence analysis showed that the strains are closely related to members of the non-phototrophic genera Octadecabacter (92.0-92.9\%) and Ketogulonicigenium (92.2-92.6\%), as well as to aerobic phototrophs of the genera Roseivivax (92.2-92.9\%) and Roseovarius (91.7-92.4\%) within the 'Alphaproteobacteria'. The DNA G $+\mathrm{C}$ content was $66 \cdot 2 \mathrm{~mol} \%$. The unusual light-harvesting complex 2, the distinct morphological features and physiological traits of these strains as well as the phylogenetic data support the proposal of the novel genus and species Roseicyclus mahoneyensis gen. nov., sp. nov., with $\mathrm{ML}^{\top}{ }^{\top}\left(=\mathrm{DSM} 16097^{\top}=\mathrm{VKM} \mathrm{B}^{-2346^{\top}}\right)$ as the type strain.

\section{INTRODUCTION}

Mahoney Lake is a meromictic saline lake located in the south-central region of British Columbia, Canada. Interesting features of this lake include a sharp chemical discontinuity at the chemocline and high concentrations of $\mathrm{Na}^{+}, \mathrm{Ca}^{2+}, \mathrm{Mg}^{2+}$ and $\mathrm{SO}_{4}^{2-}$, leading to Mahoney Lake's classification as a sodium sulfate-dominated lake (Northcote \& Halsey, 1969; Hall \& Northcote, 1986). The primary focus of most previous microbiological investigations of Mahoney Lake has been on the extremely dense population of the purple sulfur bacterium Amoebobacter purpureus (Overman et al., 1991, 1994, 1996). However strains of the purple sulfur bacterium Thiocapsa roseopersicina, the purple non-sulfur bacterium Rhodobacter

Abbreviations: APB, aerobic phototrophic bacteria; Bchl, bacteriochlorophyll; LH, light-harvesting.

The GenBank/EMBL/DDBJ accession number for the 16S rRNA gene sequence of strain ML6 ${ }^{\top}$ is AJ 315682. capsulatus and the green sulfur bacteria Chloroherpeton thalassium and Prosthecochloris aestuarii have also been isolated from the chemocline (Overman et al., 1991). In 1997, 33 aerobic bacteriochlorophyll (Bchl)-containing strains were isolated from the oxic mixolimnion, between the surface and a depth of $5 \mathrm{~m}$. These strains included both purple non-sulfur bacteria and aerobic anoxygenic phototrophic bacteria, and exhibited a variety of interesting spectral absorption properties and morphologies (Yurkova et al., 2002).

Aerobic bacteria that contain Bchl, commonly known as aerobic phototrophic bacteria (APB), are a relatively recently discovered and taxonomically diverse group. The primary distinguishing features of the APB are the presence of Bchl incorporated into light-harvesting ( $\mathrm{LH}$ ) and reaction-centre complexes, the relatively low level of photosynthetic units per cell, the inhibition of Bchl synthesis by light, the inability to grow phototrophically under anaerobic conditions, the high mid-point potential of the 
reaction-centre primary electron carrier and the abundance of carotenoid pigments (Yurkov \& Beatty, 1998; Rathgeber et al., 2004).

The first-reported member of the APB, Erythrobacter longus, is an orange-pigmented rod-shaped bacterium that was isolated from the Bay of Tokyo some 20 years ago (Shiba et al., 1979; Shiba \& Simidu, 1982). Since that time, other APB displaying a wide range of morphologies have been described. Members of the APB have been shown to produce typical rod shapes, elongated rods displaying thread-like cells and branching, ovoid cells and coccoid cells (Yurkov \& Beatty, 1998); in addition, a highly pleomorphic member of this group, 'Citromicrobium bathyomarinum' (Yurkov et al., 1999), has been described. Although several vibrioid and spirillum-shaped genera and species have been described for the purple non-sulfur bacteria (Imhoff, 2001), no vibrioid species that are members of the APB have been identified. Here, we describe eight closely related vibrioid strains from Mahoney Lake as novel members of the APB.

\section{METHODS}

Strains and cultivation. Strains ML6 ${ }^{\mathrm{T}}$, ML16 and ML18 were isolated and cultivated on a rich organic medium, medium N1 (Yurkova et al., 2002) (containing $15 \mathrm{~g} \mathrm{Na}_{2} \mathrm{SO}_{4} \mathrm{l}^{-1}$ ), and strains ML33, ML38, ML39, ML40 and ML44 were isolated and cultivated on Medium $\mathrm{N} 4$ (containing $50 \mathrm{~g} \mathrm{Na}_{2} \mathrm{SO}_{4} \mathrm{l}^{-1}$ ) (Yurkova et al., 2002). These media were used for all of the following experiments unless otherwise noted. Strains were kept on agar plates of the above media at $4{ }^{\circ} \mathrm{C}$ for up to 2 months for short-term storage. Long-term storage was achieved by freezing (at $-70{ }^{\circ} \mathrm{C}$ ) a thick cell suspension in the above-mentioned media supplemented with $30 \%$ glycerol as a cryoprotectant.

Morphological and cytological tests. The cell size, shape and motility of late-exponential-phase cultures were determined by using phase-contrast light microscopy (Zeiss Axioskop 2 equipment). Electron-microscopic negative stains were performed by staining cells with $1.0 \%$ aqueous uranyl acetate. For thin sections, the bacteria were embedded in Epon (Canemco) after fixation with $2 \cdot 5 \%$ glutaraldehyde and $1.0 \%$ osmium tetroxide as described by Kellenberger et al. (1958).

Physiological and biochemical tests. The utilization of soluble organic substrates, Tweens, gelatin and starch, the ability to grow at different $\mathrm{pH}$ levels, the ability to ferment sugars and reduce nitrate, the ability to produce catalase and oxidase and antibiotic sensitivity were determined as previously described (Yurkov \& van Gemerden, 1993; Yurkov et al., 1994). Growth at different salinities was tested in tubes containing the above-described media with $\mathrm{NaCl}$ or $\mathrm{Na}_{2} \mathrm{SO}_{4}$ at concentrations of $0,0 \cdot 5,2 \cdot 0,4 \cdot 0,6 \cdot 0,8 \cdot 0,10 \cdot 0,12 \cdot 0$ or $14 \cdot 0 \%$, incubated aerobically on a test-tube rotor at $30^{\circ} \mathrm{C}$. Photoheterotrophic growth under anaerobic conditions was tested in screwcapped test tubes and in agar deeps containing the above-described media, a basal medium, designed for purple sulfur bacteria (Imhoff, 1988), containing $\mathrm{H}_{2} \mathrm{~S}$ or $\mathrm{Na}_{2} \mathrm{~S}_{2} \mathrm{O}_{3}$ and $\mathrm{CO}_{2}$ with or without acetate, or a basal medium for purple non-sulfur bacteria (Imhoff, 1988) containing acetate, malate or succinate as the sole source of organic carbon. Tubes were incubated at $30^{\circ} \mathrm{C}$ with tungsten-filament lamp illumination of about $30 \mu \mathrm{E} \mathrm{m} \mathrm{m}^{-2} \mathrm{~s}^{-1}$.

Pigment analysis. Spectral absorption measurements were performed on strains grown under aerobic conditions in liquid culture.
Cell samples were collected by centrifugation and resuspended in $125 \mu 10 \mathrm{mM}$ Tris/HCl buffer ( $\mathrm{pH} \mathrm{7 \cdot 8)}$ ) and added to $375 \mu \mathrm{l} 30 \%$ BSA solution (ICN Biomedicals) to reduce light-scattering. Absorption spectra were recorded using a Hitachi U-2010 spectrophotometer.

DNA G+C content determination. The DNA G $+\mathrm{C}$ content was determined by using HPLC (with Shimadzu apparatus) (Tamaoka \& Komagata, 1984) of nucleotides obtained according to Mesbah \& Whitman (1989).

165 rRNA gene sequence analysis. Extraction of genomic DNA, PCR-mediated amplification of the 16S rRNA gene sequences and direct sequencing of the purified PCR products were carried out as described by Rainey et al. (1996). The sequence reaction mixtures were electrophoresed using a model 373A automatic DNA sequencer (Applied Biosystems). The partial 16S rRNA gene sequences were aligned with published sequences obtained from the EMBL nucleotide sequence database and the Ribosomal Database Project, using the ae2 editor (Maidak et al., 1996), so that similarity values could be determined.

\section{RESULTS AND DISCUSSION}

\section{Isolation}

The strains examined in this taxonomic description were isolated from the meromictic Mahoney Lake in southcentral British Columbia, Canada, in October 1997. Details of the isolation and enumeration of these bacteria were given by Yurkova et al. (2002).

\section{Culture properties}

All strains formed small, $\sim 2 \mathrm{~mm}$-diameter pink-purple to purple colonies on the surface of agar media. In liquid media under aerobic conditions, cultures appear pink-purple after $24 \mathrm{~h}$, becoming more purple with age.

Growth did not occur anaerobically in either light or dark conditions, and light was not required for growth under aerobic conditions, which led us to designate them as APB (Yurkov \& Beatty, 1998).

\section{Morphology and cytology}

Morphology was examined in exponential-phase cells grown in rich organic medium (described above) under aerobic conditions. Strains ML6 ${ }^{\mathrm{T}}$, ML16, ML18, ML33, ML38, ML39, ML40 and ML44 shared a similar morphology, which varied from elongated rods to slightly curved rods to vibrioid, almost cyclical cells (Fig. 1a). Elongated rods were $0.6 \times 2.6 \mu \mathrm{m}$ in size, while vibrioid cells were $0 \cdot 6-0 \cdot 7 \times 2 \cdot 7-3 \cdot 0 \mu \mathrm{m}$. This morphology is similar to that of the purple non-sulfur bacterium Rhodocyclus purpureus (Pfennig, 1978), except that our isolates had pointed ends rather than flat to rounded ends.

Transmission electron microscopy (using Zeiss 10C equipment) of negatively stained cells showed the pointed regions at the poles to be electron dense (Fig. 1b), while electron microscopy of thin sections indicated that these polar zones are actually due to an enlarged periplasmic space found in 

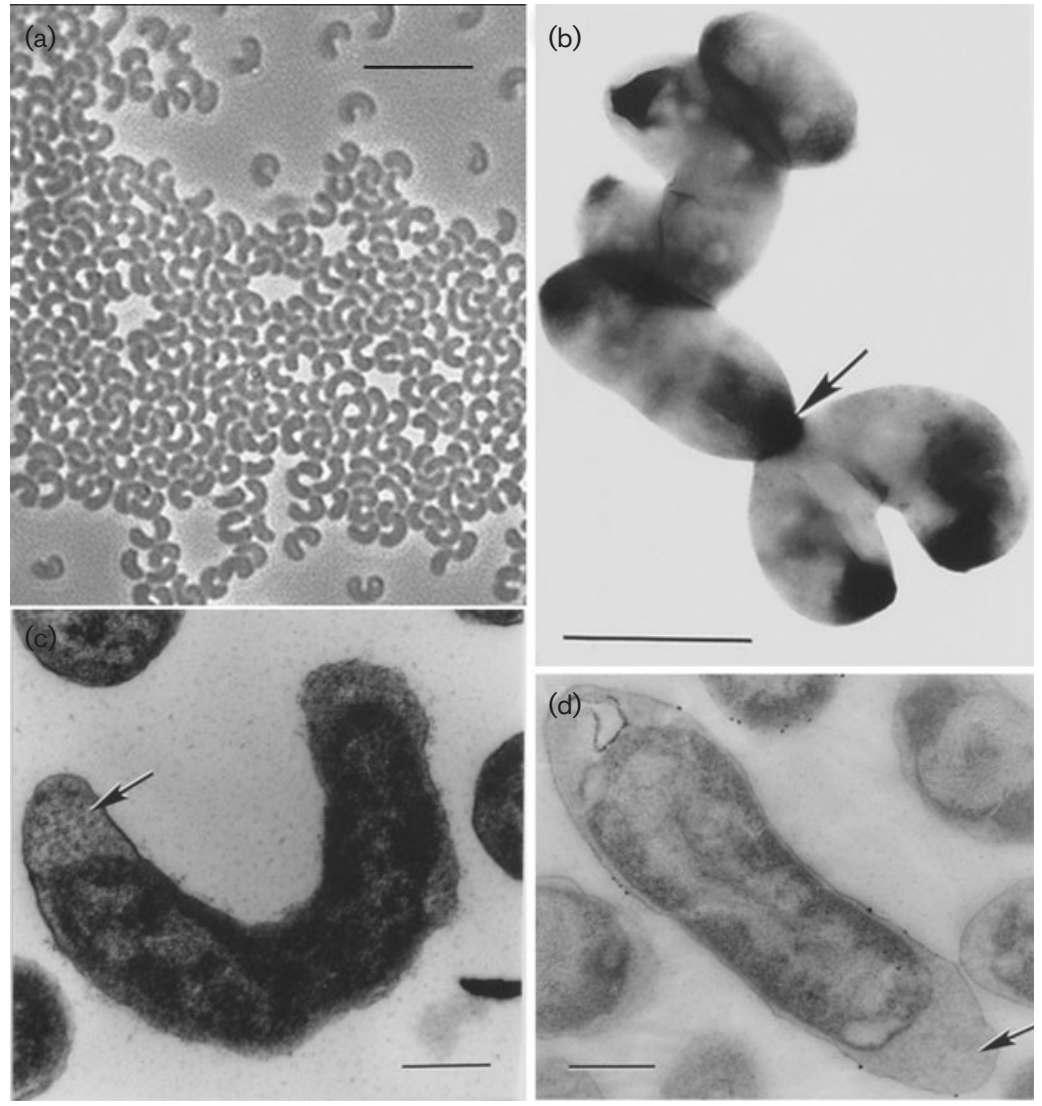

Fig. 1. (a) Phase-contrast microscopy of strain $M L 6^{\top}$ showing cyclical shaped cells. (b) Negatively stained cells with polar dark colouration of pointed ends. (c, d) Ultrathin sections of cells show polar periplasmic modifications [confirming polar staining in (b); indicated by arrows]. Bars: (a), $5 \mu \mathrm{m}$; (b), $0.5 \mu \mathrm{m}$; (c, d), $0.25 \mu \mathrm{m}$.

both rod-shaped and vibrioid cells (Fig. 1c, d). The appearance is similar to that seen in Rhodospirillum tenue (Pfennig, 1969), although the significance of these polar, periplasmic structures is unclear. Polar localization of proteins critical for cell division, chromosome partitioning and cell-cycle control in Escherichia coli, Bacillus subtilis and Caulobacter crescentus have been described. Bacterial polarity seems to play a critical role in cell structure and life cycles (Lybarger \& Maddock, 2001).

The above-mentioned strains are all non-motile. Cell division in strain ML6 $^{\mathrm{T}}$ occurs by way of symmetric and asymmetric constrictions.

The Gram-negative structure of the cell wall was confirmed by the electron-microscopic thin sections, but intracytoplasmic membrane formations, of the type usually found in true anoxygenic phototrophs, were not observed, which is typical of the APB (Fig. 1c, d). Cells contained electronclear inclusions presumably due to storage of poly- $\beta$ hydroxyalkanoates.

The unusual morphological characteristics of these strains, ranging from rod shapes through vibrioid shapes to cyclical shapes, as well as the pointed periplasmic space, have not been previously reported in the APB (Yurkov \& Beatty, 1998). Thus, these isolates are an exciting new addition to this already morphologically diverse group.

\section{Photosynthetic apparatus}

Absorption spectra for the representative strain ML6 $^{\mathrm{T}}$ are shown in Fig. 2. As for all the strains in the present study, the spectra showed in vivo Bchl $a$ peaks at 805-806 $\mathrm{nm}$ and at $870-871 \mathrm{~nm}$. The $870-871 \mathrm{~nm}$ peak is indicative of the LH1 complex, and the peak at $805-806 \mathrm{~nm}$ is indicative of a peripheral LH2 complex. This unusual organization of the

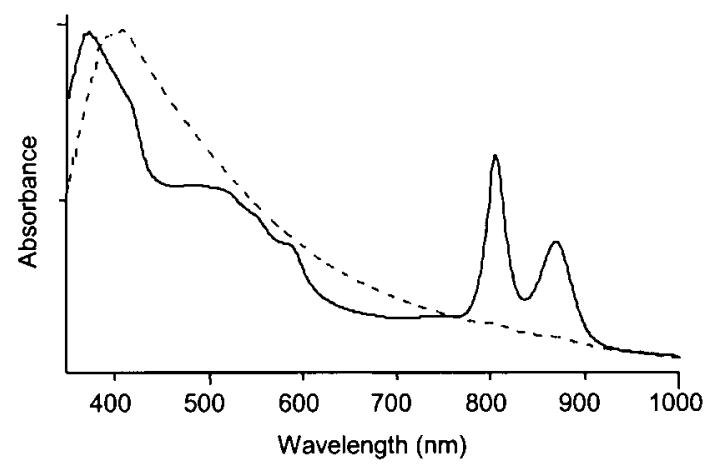

Fig. 2. Absorption spectra of intact cells of strain $M L 6^{\top}$ grown aerobically in the dark (solid line), showing peaks at 805 and $870 \mathrm{~nm}$ corresponding to Bchl incorporated into the LH2 and LH1 complexes, respectively. These peaks are reduced or absent in cells grown aerobically in the presence of continuous illumination (broken line). 
photosynthetic apparatus, where the LH2 complex has only one peak at approximately $805 \mathrm{~nm}$, has been found in only two genera of the APB so far, namely Roseobacter (Shiba,
1991) and Rubrimonas (Suzuki et al., 1999), both of which have morphological and physiological characteristics quite distinct from those of our isolates. The presence of a

Table 1. Comparative physiological characteristics of the aerobic phototrophic strains isolated from Mahoney Lake and close phylogenetic relatives

Symbols: + , substrate is utilized, substrate is hydrolysed or antibiotic-sensitive; ++ , substrate is utilized for very good growth; - , substrate is not utilized, substrate is not hydrolysed or antibiotic-resistant; W, very weak growth; NG, no growth; NA, not available. Reference strains were Roseobacter litoralis (Och $149^{\mathrm{T}}$ ), Roseivivax halodurans (Och $239^{\mathrm{T}}$ ) and Roseovarius tolerans $\left(\right.$ EL-172 ${ }^{\mathrm{T}}$ ). None of the strains shown utilized methanol and all were sensitive to chloramphenicol.

\begin{tabular}{|c|c|c|c|c|c|c|c|c|c|c|c|}
\hline Characteristic & \multicolumn{8}{|c|}{ Mahoney Lake strains } & \multicolumn{3}{|c|}{ Reference strains } \\
\hline \multicolumn{12}{|l|}{ Growth at: } \\
\hline $4^{\circ} \mathrm{C}$ & - & - & - & - & + & - & - & - & + & & + \\
\hline $10{ }^{\circ} \mathrm{C}$ & + & - & - & + & + & + & + & + & + & & ++ \\
\hline $28^{\circ} \mathrm{C}$ & ++ & ++ & ++ & ++ & ++ & ++ & ++ & ++ & + & $+^{*}$ & ++ \\
\hline \multicolumn{12}{|l|}{ Growth at $\mathrm{pH}$ : } \\
\hline $5 \cdot 5$ & - & - & - & - & - & - & - & - & - & & - \\
\hline $6 \cdot 0$ & ++ & ++ & ++ & ++ & ++ & ++ & ++ & ++ & - & & - \\
\hline $7 \cdot 0$ & ++ & ++ & ++ & ++ & ++ & ++ & ++ & ++ & - & & + \\
\hline $8 \cdot 0$ & ++ & ++ & ++ & ++ & ++ & ++ & ++ & ++ & + & $+^{*}$ & + \\
\hline \multicolumn{12}{|l|}{ Utilization of: } \\
\hline Acetate & + & + & + & - & - & - & $\mathrm{W}$ & - & + & + & + \\
\hline Pyruvate & + & + & + & - & + & - & $\mathrm{w}$ & $\mathrm{W}$ & + & + & + \\
\hline Glutamate & + & + & + & - & + & - & - & $\mathrm{W}$ & + & + & + \\
\hline Butyrate & - & + & - & - & - & - & - & - & - & + & + \\
\hline Citrate & + & - & + & $\mathrm{W}$ & + & + & + & + & + & + & - \\
\hline Malate & + & + & + & - & + & - & - & - & + & + & + \\
\hline Succinate & + & + & + & - & + & - & - & $\mathrm{W}$ & + & + & + \\
\hline Lactate & + & + & + & - & + & - & $\mathrm{W}$ & + & NA & + & - \\
\hline Formate & - & - & - & - & - & - & - & - & NA & $\mathrm{NA}$ & NA \\
\hline Fructose & ++ & ++ & ++ & - & + & + & + & + & NA & + & + \\
\hline \multicolumn{12}{|c|}{ Antibiotic sensitivity } \\
\hline Penicillin G & - & - & - & - & - & - & - & - & + & - & + \\
\hline Streptomycin & + & + & - & - & - & - & - & - & + & + & + \\
\hline Polymixin B & + & + & + & + & + & + & + & + & + & $\mathrm{NA}$ & - \\
\hline Tetracycline & + & + & + & + & + & + & + & - & NA & - & + \\
\hline Ampicillin & - & - & - & - & - & - & - & - & NA & NA & NA \\
\hline Kanamycin & + & + & - & - & - & - & - & - & NA & NA & NA \\
\hline Nalidixic acid & - & - & - & - & - & - & - & - & NA & NA & NA \\
\hline
\end{tabular}

${ }^{\star}$ Only optimum temperature and $\mathrm{pH}$ have been published (Suzuki et al., 1999). 
relatively small reaction-centre peak located in the region of $800 \mathrm{~nm}$ is masked by the strong LH2 peak at $805 \mathrm{~nm}$, as indicated in other experiments in which the reaction centre and LH complexes were purified from the photosynthetic membranes of ML6 $^{\mathrm{T}}$ (C. Rathgeber, J. Alric, A. Vermeglio and V. Yurkov, unpublished).

These isolates lack absorption peaks in both the 805 and $870 \mathrm{~nm}$ regions when grown aerobically in the presence of continuous illumination (as shown for strain $\mathrm{ML6}^{\mathrm{T}}$ in Fig. 2). This trait further confirms the identification of these strains as members of the APB. All strains show similar carotenoid peaks at approximately 408 and $484 \mathrm{~nm}$.

\section{Biochemical and physiological data}

A variety of physiological characteristics are presented in Table 1. All of the isolates produce both catalase and cytochrome $c$ oxidase.

The group of strains represented by ML6 $6^{\mathrm{T}}$ shows an absolute requirement for saline conditions, being unable to grow at concentrations of $\mathrm{NaCl}$ or $\mathrm{Na}_{2} \mathrm{SO}_{4}$ (or presumably another compatible solute) below $0.5 \%$. The upper salinity limits for all of the strains are similar. All strains grow at $\mathrm{Na}_{2} \mathrm{SO}_{4}$ concentrations up to $10 \%$, while the upper limit for $\mathrm{NaCl}$ is between 6 and $10 \%$ (differing between strains).

All strains tolerate a wide range of $\mathrm{pH}$ values and grow between $\mathrm{pH} 6 \cdot 0$ and $11 \cdot 0$, the latter being the highest value tested.

In a previous study, 33 Mahoney Lake isolates were categorized into three groups based on their ability to utilize organic substrates as sole sources of carbon and energy (Yurkova et al., 2002). The largest group was made up of strains that were able to utilize a wide range of substrates. A second group contained strains with very restricted metabolic abilities and which could utilize only a limited number of organic substrates. A third and final group was made up of strains that did not grow in any media containing only single organic compounds because they require a complex organic source such as yeast extract (Yurkova et al., 2002). The strains described herein fall into all three previously described groups, as shown in Table 1, indicating that the ability to utilize organic substrates is not an adequate taxonomic marker for the APB isolated from Mahoney Lake, where even highly similar and highly related strains show great differences in organic carbon preference.

The isolates described in this paper cannot be repeatedly transferred and cultivated on minimal media in the absence of yeast extract. This indicates that they require an unknown growth factor present in yeast extract. Other strains from Mahoney Lake have been shown to be dependent on vitamin $\mathrm{B}_{12}$ and/or biotin (Yurkova et al., 2002); however, the addition of these vitamins to minimal media was not sufficient to allow the successive cultivation of these isolates.

As is common for the APB, there was variable sensitivity to antibiotics (Table 1). Again, this trait does not appear to be a useful taxonomic marker, as highly similar, highly related strains show markedly different responses to the antibiotics tested.

\section{DNA composition and phylogenetic analysis}

On the basis of the analysis of almost-complete 16S rRNA gene sequences ( $>1430$ nucleotides), strain $\mathrm{ML}^{\mathrm{T}}$ is a member of the $\alpha-3$ group of the Proteobacteria, within the Roseobacter clade (Fig. 3). On the basis of the analysis of the algorithm of De Soete (1983), neighbour-joining and maximum-likelihood, strain $\mathrm{ML6}^{\mathrm{T}}$, along with the purple non-sulfur strain ML42 (Yurkova et al., 2002), define a novel lineage. As bootstrap values are at this level very low, the branching point may change when novel sequences are included. The phylogenetic distance between ML6 $^{\mathrm{T}}$ and ML42 $(96.9 \%)$ is like that which is generally found for well-separated species. However, physiological differences clearly place them in different genera (Yurkova et al., 2002). Strain ML6 $^{\mathrm{T}}$ shares less than $93.0 \% 16 \mathrm{~S}$ rRNA gene sequence similarity with its phylogenetically closest taxonomically characterized relatives, i.e. members of the non-phototrophic genera Octadecabacter (92.0-92.9\%) and Ketogulonicigenium $(92 \cdot 2-92 \cdot 6 \%)$ and the APB

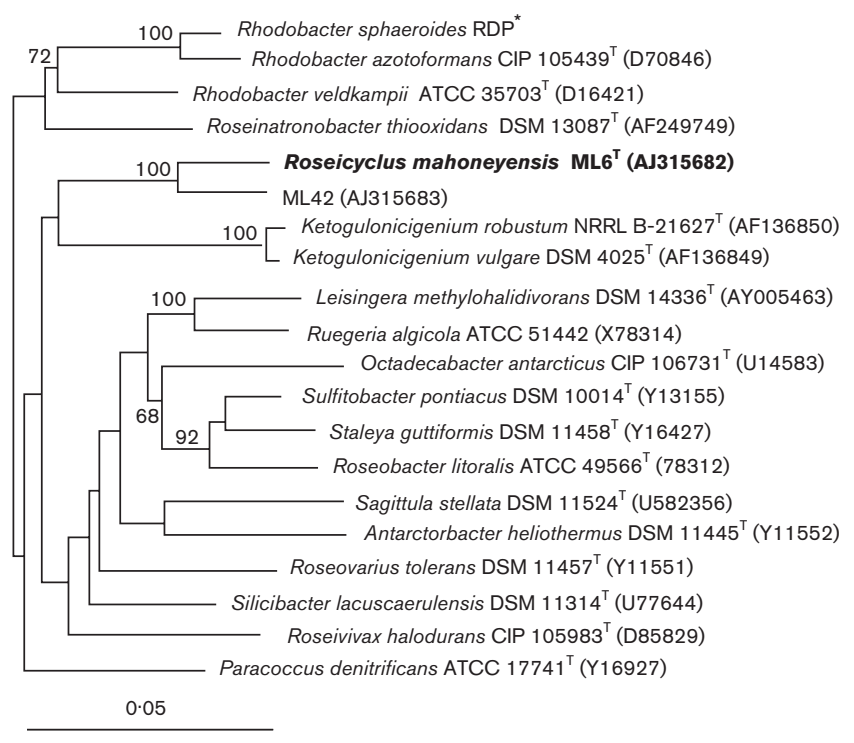

Fig. 3. Neighbour-joining dendrogram of $16 \mathrm{~S}$ rRNA gene sequence relatedness, showing the position of Roseicyclus mahoneyensis strain $\mathrm{ML}^{\top}$ and its phylogenetic neighbours, i.e. the purple non-sulfur strain ML42, members of the genera Ketogulonicigenium and other members of the Roseobacter clade, $\alpha-3$ cluster of the Proteobacteria. Bootstrap values (500 resamplings) that support branching points above $90 \%$ confidence are indicated. The tree was rooted with the 16S rRNA gene sequences of other members of the 'Alphaproteobacteria'. The asterisk indicates a sequence deposited in the Ribosomal Database Project (http://rdp.cme.msu.edu/index.jsp) rather than EMBL. Bar, 5 substitutions per 100 sequence positions. 
species Roseivivax halodurans $(92 \cdot 2-92 \cdot 9 \%)$ and Roseovarius tolerans $(91 \cdot 7-92 \cdot 4 \%)$.

\section{Concluding remarks}

The presence of $\mathrm{Bchl} a$ incorporated into the reaction centre, the LH1 and LH2 complexes, the inability to grow photoheterotrophically under anaerobic conditions, the strong inhibition of Bchl synthesis by light and the absence of an intracytoplasmic membrane system prompt us to conclude that all of the novel strains described in this work are indeed members of the APB.

The phylogenetic analysis revealed that these strains have identical rRNA gene sequences and constitute a distinct branch closely related to the chemotrophic genera Octadecabacter and Ketogulonicigenium, as well as to phototrophs of the genera Roseivivax and Roseovarius.

Morphological, physiological and biochemical properties allow us to differentiate the novel strains easily from their close phylogenetic neighbours in the genera Octadecabacter and Ketogulonicigenium. Members of the genus Octadecabacter are obligate psychrophiles and form rod-shaped cells containing gas vacuoles (Gosink et al., 1997), whereas Ketogulonicigenium species are facultatively anaerobic, ovoid rods that exhibit relatively narrow $\mathrm{pH}$, temperature and salinity ranges (Urbance et al., 2001). Neither Octadecabacter nor Ketogulonicigenium species form the vibrioid or cyclical cells characteristic of our Mahoney Lake isolates, and neither contain Bchl $a$ or carotenoid pigments, although all species of Ketogulonicigenium produce an unidentified, water-soluble, brown pigment.

Additionally, the strains represented by $\mathrm{ML6}^{\mathrm{T}}$ differ significantly from their closest phototrophic relatives, members of the genera Roseivivax and Roseovarius, in terms of their cellular morphology and photosynthetic LH apparatus. Although both Roseivivax and Roseovarius were isolated from a similar habitat (i.e. a saline lake) and exhibit broad tolerance to saline conditions similar to that found in the Mahoney Lake isolates, they do not produce a peripheral LH2 complex and form normal motile rods (Suzuki et al., 1999; Labrenz et al., 1999).

On the basis of these important taxonomic markers and the low $16 \mathrm{~S}$ rRNA gene sequence similarity $(<93.0 \%)$ between the novel isolates and their closest phylogenetic relatives, we propose the novel genus Roseicyclus, with Roseicyclus mahoneyensis as the type species.

\section{Description of Roseicyclus gen. nov.}

Roseicyclus (Ro.se.i.cyc'lus. L. adj. roseus rose, pink; L. masc. n. cyclus cycle; N.L. masc. n. Roseicyclus pink cyclic bacterium).

Cells are Gram-negative and are ovoid to elongated rods, vibrioid or almost cyclical. Produce pointed enlarged areas of the periplasm located at the poles. Non-motile. Divide by means of symmetric or asymmetric constrictions. Cultures are pink-purple to purple due to the production of carotenoids and Bchl $a$. Produce both LH1 complex, with an absorption peak at $870-871 \mathrm{~nm}$, and an interesting LH2 complex with one absorption peak at $805-806 \mathrm{~nm}$. No growth occurs anaerobically in the light. Obligately aerobic; no fermentation or dissimilatory denitrification observed. The habitat of the first isolated strains is a saline, $\mathrm{Na}_{2} \mathrm{SO}_{4}$ dominated lake. Member of the 'Alphaproteobacteria'. The type species is Roseicyclus mahoneyensis.

\section{Description of Roseicyclus mahoneyensis sp. nov.}

Roseicyclus mahoneyensis (ma.ho.ney.en'sis. N.L. masc. adj. mahoneyensis from Mahoney Lake, where the species was originally isolated).

Shows the following properties in addition to those given for the genus. Cells are elongated rods $(0.6 \times 2.6 \mu \mathrm{m})$ or vibrioid cells $(0 \cdot 6-0 \cdot 7 \times 2 \cdot 7-3 \cdot 0 \mu \mathrm{m})$. Bchl gives in vivo absorption spectrum peaks at $805-806$ and $870-871 \mathrm{~nm}$. Aerobic organoheterotroph and facultative photoheterotroph. Best substrate for growth is yeast extract; growth also occurs on acetate, pyruvate, glutamate, butyrate, citrate, malate, succinate, lactate, fructose and glucose, depending on the strain. Strains differ in their ability to hydrolyse starch and Tween 60; all strains hydrolyse gelatin. Optimum temperature for growth is $30^{\circ} \mathrm{C}$, with growth occurring at temperatures as low as $4{ }^{\circ} \mathrm{C}$ and as high as $37^{\circ} \mathrm{C}$, depending on the strain. Absolute requirement for saline conditions, with growth occurring over a wide range of $\mathrm{NaCl}$ and $\mathrm{Na}_{2} \mathrm{SO}_{4}$ concentrations, from 0.5 to $10 \%$. Growth occurs over a wide range of $\mathrm{pH}$ values, from $\mathrm{pH} 6 \cdot 0$ to $11 \cdot 0$. May or may not be resistant to a variety of antibiotics including penicillin G, streptomycin, tetracycline, ampicillin, kanamycin and nalidixic acid, depending on the strain. Requires an unidentified growth factor present in yeast extract. The DNA G $+\mathrm{C}$ content is $66 \cdot 2 \mathrm{~mol} \%$.

The habitat of the first isolated strains is the meromictic saline Mahoney Lake in south-central British Columbia, Canada. The type strain is ML6 $^{\mathrm{T}}\left(=\mathrm{DSM} 16097^{\mathrm{T}}=\mathrm{VKM}\right.$ B- $\left.2346^{\mathrm{T}}\right)$.

\section{ACKNOWLEDGEMENTS}

This research was funded by grants from the NSERC (Canada) to V. Y. and J. T. B. We thank K. J. Hall and T. G. Northcote for collection of samples from Mahoney Lake and H. G. Trüper for assistance with the nomenclature.

\section{REFERENCES}

De Soete, G. (1983). A least squares algorithm for fitting additive trees to proximity data. Psychometrika 48, 621-626.

Gosink, J. J., Herwig, R. P. \& Staley, J. T. (1997). Octadecabacter arcticus gen. nov., sp. nov., and O. antarcticus, sp. nov., 
nonpigmented, psychrophilic gas vacuolated bacteria from polar sea ice and water. Syst Appl Microbiol 20, 356-365.

Hall, K. J. \& Northcote, T. G. (1986). Conductivity-temperature standardization and dissolved solids estimation in a meromictic saline lake. Can J Fish Aquat Sci 43, 2450-2454.

Imhoff, J. F. (1988). Anoxygenic phototrophic bacteria. In Methods in Aquatic Bacteriology, pp. 207-240. Edited by B. Austin. New York: Wiley.

Imhoff, J. F. (2001). The phototrophic alpha-Proteobacteria. In The Prokaryotes: an Evolving Electronic Resource for the Microbiological Community, 3rd edn, release 3.6, 22 June 2001. Edited by M. Dworkin et al. New York: Springer. http://link.springer-ny.com/ link/service/books/10125/

Kellenberger, E., Ryter, A. \& Sechaud, J. (1958). Electron microscope study of DNA-containing plasms. II. Vegetative and mature phage DNA as compared with normal bacterial nucleoids in different physiological states. J Biophys Biochem Cytol 4, 671-678.

Labrenz, M., Collins, M. D., Lawson, P. A., Tindall, B. J., Schumann, P. \& Hirsch, P. (1999). Roseovarius tolerans gen. nov., sp. nov., a budding bacterium with variable bacteriochlorophyll $a$ production from hypersaline Ekho Lake. Int J Syst Bacteriol 49, 137-147.

Lybarger, S. R. \& Maddock, J. R. (2001). Polarity in action: asymmetric protein localization in bacteria. J Bacteriol 183, 3261-3267.

Maidak, B. L., Olsen, G. J., Larsen, N., Overbeek, R., McCaughey, M. J. \& Woese, C. R. (1996). The Ribosomal Database Project (RDP). Nucleic Acids Res 24, 82-85.

Mesbah, M. \& Whitman, W. B. (1989). Measurement of deoxyguanosine/thymidine ratios in complex mixtures by high-performance liquid chromatography for determination of the mole percentage guanine + cytosine of DNA. J Chromatogr 479, 297-306.

Northcote, T. G. \& Halsey, T. G. (1969). Seasonal changes in the limnology of some meromictic lakes in southern British Columbia. J Fish Res Board Can 26, 1763-1787.

Overman, J., Beatty, J. T., Hall, K. J., Pfennig, N. \& Northcote, T. G. (1991). Characterization of a dense, purple sulfur bacterial layer in a meromictic salt lake. Limnol Oceanogr 36, 846-859.

Overman, J., Beatty, J. T. \& Hall, K. J. (1994). Photosynthetic activity and population dynamics of Amoebobacter purpureus in a meromictic saline lake. FEMS Microbiol Ecol 15, 309-320.

Overman, J., Beatty, J. T. \& Hall, K. J. (1996). Purple sulfur bacteria control the growth of aerobic heterotrophic bacterioplankton in a meromictic salt lake. Appl Environ Microbiol 62, 3251-3258.

Pfennig, N. (1969). Rhodospirillum tenue sp. n., a new species of the purple nonsulfur bacteria. J Bacteriol 99, 619-620.

Pfennig, N. (1978). Rhodocyclus purpureus gen. nov. and sp. nov., a ring-shaped vitamin B12-requiring member of the family Rhodospirillaceae. Int J Syst Bacteriol 28, 283-288.
Rainey, F. A., Ward-Rainey, N., Kroppenstedt, R. M. \& Stackebrandt, E. (1996). The genus Nocardiopsis represents a phylogenetically coherent taxon and a distinct actinomycete lineage: proposal of Nocardiopsaceae fam. nov. Int J Syst Bacteriol 46, 1088-1092.

Rathgeber, C., Beatty, J. T. \& Yurkov, V. (2004). Aerobic phototrophic bacteria: new evidence for the diversity, ecological importance and applied potential of this previously overlooked group. Photosynth Res 81, 113-128.

Shiba, T. (1991). Roseobacter litoralis gen. nov., sp. nov. and Roseobacter denitrificans sp. nov., aerobic pink-pigmented bacteria which contain bacteriochlorophyll a. Syst Appl Microbiol 14, 140-145.

Shiba, T. \& Simidu, U. (1982). Erythrobacter longus gen. nov., sp. nov., an aerobic bacterium which contains bacteriochlorophyll $a$. Int $J$ Syst Bacteriol 32, 211-217.

Shiba, T., Simidu, U. \& Taga, N. (1979). Distribution of aerobic bacteria which contain bacteriochlorophyll a. Appl Environ Microbiol 38, $43-45$.

Suzuki, T., Muroga, Y., Takahama, M. \& Nishimura, Y. (1999). Roseivivax halodurans gen. nov., sp. nov. and Roseivivax halotolerans sp. nov., aerobic bacteriochlorophyll-containing bacteria isolated from a saline lake. Int J Syst Bacteriol 49, 629-634.

Tamaoka, J. \& Komagata, K. (1984). Determination of DNA base composition by reversed-phase high-performance liquid chromatography. FEMS Microbiol Lett 25, 125-128.

Urbance, J. W., Bratina, B. J., Stoddard, S. F. \& Schmidt, T. M. (2001). Taxonomic characterization of Ketogulonigenium vulgare gen. nov., sp. nov., and Ketogulonigenium robustum sp. nov., which oxidize L-sorbose to 2-keto-L-gulonic acid. Int J Syst Evol Microbiol 51, 1059-1070.

Yurkov, V. V. \& Beatty, J. T. (1998). Aerobic anoxygenic phototrophic bacteria. Microbiol Mol Biol Rev 62, 695-724.

Yurkov, V. \& van Gemerden, H. (1993). Abundance and salt tolerance of obligately aerobic, phototrophic bacteria in a microbial mat. Neth J Sea Res 31, 57-62.

Yurkov, V., Stackebrandt, E., Holmes, A. \& 7 other authors (1994). Phylogenetic positions of novel aerobic, bacteriochlorophyll acontaining bacteria and description of Roseococcus thiosulfatophilus gen. nov., sp. nov., Erythromicrobium ramosum gen. nov., sp. nov., and Erythrobacter litoralis sp. nov. Int J Syst Bacteriol 44, 427-434.

Yurkov, V. V., Krieger, S., Stackebrandt, E. \& Beatty, J. T. (1999). Citromicrobium bathyomarinum, a novel aerobic bacterium isolated from deep-sea hydrothermal vent plume waters that contains photosynthetic pigment-protein complexes. J Bacteriol 181, 4517-4525.

Yurkova, N., Rathgeber, C., Swiderski, J., Stackebrandt, E., Beatty, J. T., Hall, K. J. \& Yurkov, V. (2002). Diversity, distribution and physiology of the aerobic phototrophic bacteria in the mixolimnion of a meromictic lake. FEMS Microbiol Ecol 40, 191-204. 